\title{
Ethnopharmacological and Genetic Study on the Treatment of Mental Disorders: a Systematic Review
}

Carlos Kennedy Tavares Lima ${ }^{6}$, Larissa Queiroz Pontes ${ }^{1}$, Lia Gonçalves Pinho1, Marcus Rafael Lobo Bezerra1, Wallady da Silva Barroso1, Antonio Gilvan Teixeira Júnior2, Maria Nizete Tavares Alves ${ }^{3}$, Janaina Carvalho Braz Macêdo4, Uilna Natercia Soares Feitosa ${ }^{4}$, José Leandro de Almeida Neto ${ }^{5}$, Carmem Ulisses Peixoto ${ }^{6}$, Maria Eliana Pierre Martins ${ }^{6}$, Modesto Leite Rolim-Neto ${ }^{2}$

\section{Abstract}

Background: Popular medicine has been used to treat some diseases including mental disorders since the ancient times. The development of this powerful tool can bring to the actual world some benefits to improve the way of taking care of mental illnesses.

Objective: To show relevant studies about biopharmaceuticals and to infer the equivalence of using biopharmaceuticals, regarding to efficacy and safety as the chemical-type drugs in the treatment for mental disorders, assessing whether there are biomolecules that might work as biopharmaceuticals to treat, cure or mitigate different mental disorders.

Methods: A systematic review from 01.01.2004 to 25.28.2014 was performed on the databases PubMed, Scopus and Science Direct. The search was performed with the descriptor "mental disorders" and with the keywords "biopharmaceuticals" and "biomolecules". The information pertinent to the study was selected, categorized and analyzed. Of the 339 articles found, 20 met the eligibility criteria.

Results: Eastern culture, followed by Amazonian region concentrated most of the species related with popular treatment of mental disorders. Several species were revealed to act upon receptors or neurotransmitters in the Central Nervous System (CNS), which, sometimes, is a similar mechanism of action of a lot of well-known synthetic drugs on the market. It was also highlighted the use of the genetic knowled-
1 Department of Biochemistry and Molecular Biology. Federal University of Ceara, UFC, Fortaleza, Ceara, Brazil.

2 Faculty of Medicine. Federal University of Cariri, UFCA, Barbalha, Ceara, Brazil.

3 Nursing Course, Regional University Cariri - URCA, Crato, Ceará, Brazil.

4 Basic Health, Health's Secretary of Juazeiro do Norte, Ceará, Brazil.

5 Faculty of Applied Sciences - Dr. Leão Sampaio, Juazeiro do Norte, Ceará, Brazil.

6 Post Graduate in Science of Health, Faculty of Medicine ABC, Santo André, São Paulo, Brazil.

Contact information:

Modesto Leite Rolim-Neto.

Address: 4284, Divine Savior Street, Downtown, Barbalha, Ceará, Brazil, 63180000 .

Tel: +055(88)96896006.

”modestorolim@yahoo.com.br 
ge to propose a gene therapy, in which a more targeted treatment would be available in cases of mental illnesses.

Conclusion: Our findings consolidate the importance of popular medicine to society. In this study, the reported natural compounds have been used for many years to treat mental disorders confirming their potential activity as biopharmaceuticals. Also, possible targets were reported for gene therapy, a promising approach to treat mental illnesses.

\section{Keywords}

Treatment of

Mental Disorders;

Ethnopharmacological;

Genetic Study.

\section{Introduction}

It is estimated that $70 \%$ to $80 \%$ of people worldwide rely chiefly on traditional, largely herbal medicine to meet their primary health care needs. It has further been observed that a number of modern pharmaceuticals have been derived from plants used by indigenous people. Many modern drugs have been derived from observations of traditional medicinal use including aspirin, atropine, ephedrine, digoxin, morphine, quinine, reserpine, and tubocurarine. Out of the 350,000 plant species identified so far, about 35,000 (some estimated up to 70,000) are used worldwide for medicinal purposes, and less than about $0.5 \%$ of these have been chemically investigated [1, 2-8].

Taken together the major mental disorders, schizophrenia and bipolar disorder, affect almost 2\% of the adult population and are a major cause of global disability. In the absence of a clear understanding of the pathophysiological processes involved, diagnosis is based on a clinical assessment of symptoms (e.g., delusions, hallucinations, depression and mania) and course of illness. Both disorders are still associated with substantial morbidity and premature mortality. The statistics are sobering: people with severe mental illness die on average 25 years earlier than those in the general population. Intensive investigation of known mood stabilizers (e.g., lithium) and antipsychotic medications (e.g., haloperidol and clozapine) has yet to translate into better understanding of aetiology or a breakthrough in development of new therapies leading to improved outcome [9].

Numerous psychological and brain disorder research studies have been conducted using traditional medicinal plants in the form of specific oils, herbal extracts, and combinations to treat specific diseases, including anxiety, depression, insomnia, Alzheimer's, convulsions, Parkinson's, etc. in an effort to discover new therapeutic agents that lack the toxic side effects associated with the current agents [10].

Various plant-derived essential oils (EOs) have been used in European, Arabic, and Mediterranean countries for the treatment of different illnesses [11, $12,13]$. India and China are the countries of vast biodiversity and traditional knowledge for using natural/herbal medicines to cure many ailments in various cultures and tribes. There has been a considerable popular interest in the use of herbal products, to treat anxiety disorder/reactions [10]. One possible explanation for the efficacy of EOs for mental disorders is that EOs may have central nervous system (CNS) acting effects [11, 14].

The search for new psychotropic medications for the treatment of diseases of the nervous system and mental illnesses has benefited enormously from ethnopharmacology. In the field of psychopharma- 
cology, ethnopharmacological research has uncovered a wide spectrum of CNS-active compounds ranging from sedatives to anxiolytics to analgesics to hallucinogens [15].

Depression is a serious public mental disease. It is a major cause of disability, suicide and physical disorders $[16,17]$. Depressive disorder is a prevalent psychiatric disorder, which affects $21 \%$ of the world population $[18,19]$. In search for new therapeutic products for the treatment of depression, medicinal plant research has contributed significantly by demonstrating pharmacological effectiveness of different herbs or their prescriptions [20, 21, 22].

Anxiety disorders are among the most common types of mental illnesses $[23,24]$ with a 12-month prevalence of approximately $17 \%$ and a lifetime prevalence of almost $25 \%$ in the USA [23, 25]. Despite its high prevalence, anxiety disorder is a seriously undertreated condition, and a recent mental health survey suggests that more than half of affected patients do not receive appropriate treatment $[23,26]$.

The most commonly used drugs in the pharmacological treatment of anxiety are serotonin reuptake inhibitors (SRIs) and benzodiazepines [23, 27]. Fragile $X$ syndrome, the most common cause of inherited mental retardation and autism spectrum disorders, is caused by mutations of the FMR1 gene that encodes the fragile $X$ mental retardation protein (FMRP) [28, 29-37].

Medications such as tricyclic antidepressants (TCAs), selective serotonin reuptake inhibitors (SSRIs), selective reversible inhibitors of monoamine oxidase A (RIMAs), and specific serotonin-noradrenaline reuptake inhibitors (SNRIs) are clinically employed for drug therapy $[18,38]$. Also, they can impose a variety of side-effects including cardiac toxicity, hypopiesia, sexual dysfunction, body weight gain, and sleep disorder [18, 39-42].

The present review intends to show relevant studies about biopharmaceuticals and to infer the equivalence of using biopharmaceuticals, regarding to efficacy and safety as the chemical-type drugs in the treatment for mental disorders, assessing whether there are biomolecules that might work as biopharmaceuticals to treat, cure or mitigate different mental disorders. Considering the side effects caused by intake of common prescribed drug it is of fundamental importance the replacement for natural based products that has less safety concerns with equivalent or better efficacy parameters.

\section{Methods}

It was performed a qualitative systematic review of articles about incidents biopharmaceuticals used as drugs to treat, cure or mitigate different mental disorders published in electronic databases previously selected. It was conducted a search in the literature through the online databases PubMed, Scopus and Science Direct, by limiting itself to articles published between January 1, 2009 to August 25, 2014.

The reason to limit the search between 2009 and 2014 was because before this period, the number of published works were little expressive and at the same time not addressed directly the use of biopharmaceuticals on mental disorders.

The following terms were used for, searching on the Databases:

1) Biopharmaceuticals (Keyword)

2) Biologics (Keyword)

3) Mental disorders (Medical Subject Headings $[\mathrm{MeSH}])$.

The analysis of the article followed eligibility criteria previously determined. The survey was carried out in six phases: 1 and 3; 2 and 3 on each database (Figure 1).

On PubMed, we used the filters MeSH Terms, Title/Abstract, Publication Dates, Free Full Text, and English on the strategy 1 and 3; and MeSH Terms, Title/Abstract, Publication dates, Full text, 
and English in the strategy 2 and 3 (Figure 1). On Scopus, we used the filters All, Title/Abstract/Keywords, Publication Dates, English and Document Type (Article), on the strategy 1 and 3; Abstract, Publication Dates, English and Document Type (Article), on the strategy 2 and 3 (Figure 1). On Science Direct, we used the filters Publication
Dates, Journals and Full text on the strategy 1 and 3; Publication Dates, Journals, All Fields and Abstract/Title/Keywords on the strategy 2 and 3 (Figure 1).

It was adopted the following inclusion criteria: (1) written publications in English (2) studies involving the of use of biopharmaceuticals on mental

Figure 1: Flow charting showing study selection for this review.

PubMed (Period: 01.01.2009 to 08.25.2014)
1) Biopharmaceuticals[MeSH Terms]
2) Mental disorders [Title/Abstract]
Index: Free full text
AND
3) Biologics [MeSH Terms]
4) Mental disorders [Title/Abstract]
Index: Full text

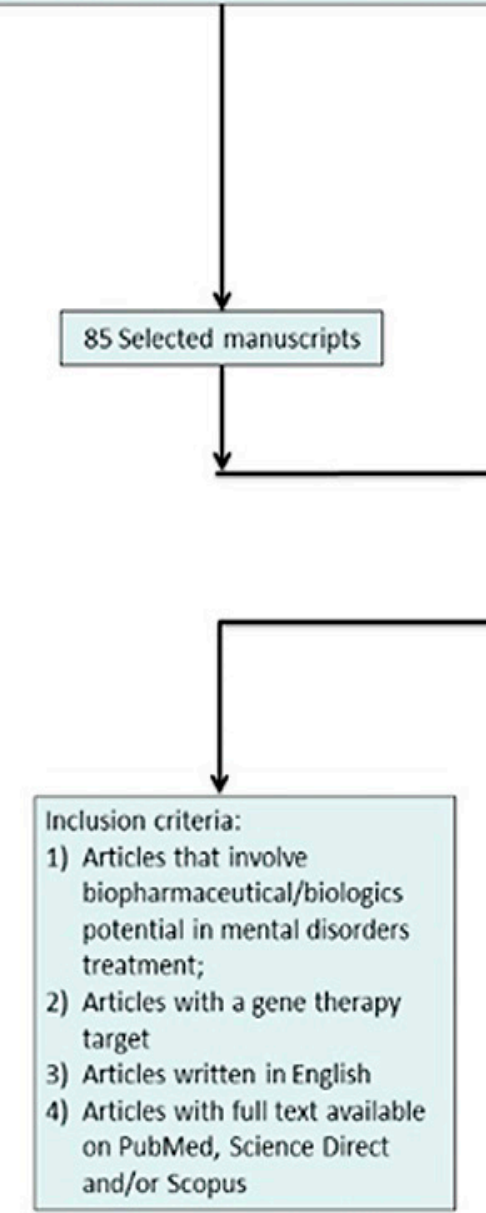

SCOPUS (Period: 01.01.2009 to 08.25.2014) 1) Biopharmaceuticals[ALL] 2) Mental disorders[Title/Abstract/Keywords] AND 3) Biologics [Abstract] 4) Mental disorders [Abstract]

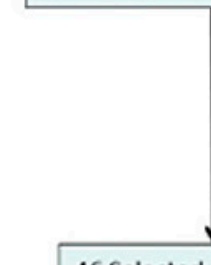

46 Selected manuscripts
Science Direct (Period 01.01.2009 to

08.25.2014) 1) Biopharmaceuticals [Full text] 2) Mental disorders [full text] AND

3) Biologics [All fields]

4) Mental disorders

[Title/Abstract/Keywords]

08 Selected manuscripts

$Z$ articles excluded after examining the title and abstract

a) No mental disorder and/or biologics discussed ( $n$ = 195);

b) Letter to editor $(n=0)$;

References to full text analyzed for eligibility; ( $n=336$ )

c) Review of Literature $(n=99)$;

d) Preface $(n=0)$

e) Commentary $(n=0)$;

f) Case Report $(n=3)$;

B) Editorial $(n=1)$;

h) Meta-analysis $(n=2)$;

i) Full text not available on SCOPUS or PUBMED or CAPES $(n=11)$;

j) Not written in English ( $n=5$ ). 
disorders; (3) original articles with full text accessible through the Portal de Periódicos CAPES (The Coordenação de Aperfeiçoamento de Pessoal de Nível Superior) a virtual library connected to the Brazilian Ministry of education with content restricted to authorized users; and (5) prospective or retrospective observational studies (descriptive or analytical, except for case studies), experimental or almost experimental. The exclusion criteria were: (1) other study designs, e.g. case reports, case series, literature reviews and comments; (2) non-original studies, including editorials, reviews, forewords, short communications and letters to the editor.

Each article was read in its entirety, and the information was entered in a spreadsheet that included authors, year of publication, the study sample description, key data, and databases. To better analyze the data, the following stage involved the comparison between the articles and the division of the results obtained from the reading of each one of them in four main categories: Relevant plants worldwide, Relationship of mechanisms of action of potential biopharmaceuticals and their correlated diseases, Comparison among biopharmaceuticals and other drugs well established on the market, Genetic variations and gene therapy perspectives related to mental disorders.

\section{Results}

Initially, the aforementioned search strategies resulted in 339 references. After browsing the title and abstract of the retrieved citations for eligibility based on study inclusion criteria, 319 articles were excluded and 20 articles were further retrieved and included in the final sample (Figure 1).

Table 1 provides an overview of all studies included in the final sample and of all data elements used during the data analysis process. The 20 studies were distributed into the previously determined four categories as follows: Relevant plants worldwide $[10,15,16,18,23,44,46,58,59$, 60] (ten studies); Relationship of mechanisms of action of potential biopharmaceuticals and their correlated diseases $[10,11,15,20,23,44,46,58$, 59] (nine studies), Comparison among biopharmaceuticals and other drugs well established on the market [10, 11, 23, 44, 46] (five studies), Genetic variations and gene therapy perspectives related to mental disorders [9, 28, 58, 93, 96, 100, 134] (seven studies).

Among the 20 studies, some studies were referenced in more than one category. The categorization of studies aims to a better organizational quality systematic review and it is not compulsory that each article must be referenced only in their respective category.

\section{Discussion}

\section{Relevant plants worldwide}

Ethnopharmacology has led to the discovery of botanical medicines or natural products useful in psychiatric disorders such as anxiety and depression, sleep disorders, and dementias [15]. A combination of screening approaches to evaluate a selected sample of Amazonian ethnomedicines for indications of CNS activities that may have therapeutic applications for the treatment of cognitive deficits was used by McKenna et al [15]. Additionally, Hypericum perforatum commonly known as St. Johns Wort; is the most well-known herbal product available over the counter [10]. Previous studies have shown that a number of plants from this family, including Salvia officinalis, Salvia elegans, Salvia reuterana, and Scutellaria baicalensis have shown anti-anxiety activity $[10,43]$. Stachystibetica is distributed in the tropical and subtropical regions of the world, including in Tibet, China, India, etc. In India, it is found in the cold desert regions of the Ladakh Valley and in the mountains of Himachal Pradesh [10]. 
Table 1. A new perspective of biopharmaceuticals and mental disorders treatment: a systematic review. Studies and main findings.

\begin{tabular}{|c|c|c|c|}
\hline Authors & Journal & Sample & Main Findings \\
\hline $\begin{array}{l}\text { Kumar } \\
\text { et al [10] } \\
\text { (2013) }\end{array}$ & $\begin{array}{l}\text { Chinese Journal of } \\
\text { Natural Medicines }\end{array}$ & 60 rats & $\begin{array}{l}\text { Methanolic extracts ( } 200 \text { and } 400 \mathrm{mg} \cdot \mathrm{kg}-1) \text { of the root, stem, leaf and whole plant of Stachys tibetica Vatke and } \\
\text { diazepam (DZ) increased the time spent and the number of entries in the open arm significantly }(* * P<0.01) \text {, while they } \\
\text { decreased the time spent and the number of entries in the closed arm. These allied parameters helped to assess the } \\
\text { anxiolytic potential of Stachys tibetica Vatke. The results strongly justify the use of this plant for the treatment of anxiety. }\end{array}$ \\
\hline $\begin{array}{l}\text { Yamaguchi } \\
\text { et al [46] } \\
\text { (2012) }\end{array}$ & $\begin{array}{l}\text { Journal of } \\
\text { Ethnopharmacology }\end{array}$ & $\begin{array}{l}\text { Male Wistar/ST } \\
\text { rats }\end{array}$ & $\begin{array}{l}\text { These findings suggested that yokukansan has anxiolytic effects on anxiety-like behaviors induced by both innate fear and } \\
\text { memory-dependent fear. }\end{array}$ \\
\hline $\begin{array}{l}\text { Gaoa } \\
\text { et al [16] } \\
(2011)\end{array}$ & $\begin{array}{l}\text { Journal of } \\
\text { Ethnopharmacology }\end{array}$ & $\begin{array}{l}56 \text { male Sprague- } \\
\text { Dawley rats }\end{array}$ & $\begin{array}{l}\text { The significant difference in metabolic profiling was observed from model group compared with drug-dose group by } \\
\text { using the Principal Component Analysis (PCA), indicating the recovery effect of XYS on Chronic Unpredictable mild Stress } \\
\text { (CUMS) rats. }\end{array}$ \\
\hline $\begin{array}{l}\text { Bisong SA, } \\
\text { Brown R, } \\
\text { Osim EE. } \\
\text { [60] (2010) }\end{array}$ & $\begin{array}{l}\text { Journal of } \\
\text { Ethnopharmacology }\end{array}$ & $\begin{array}{l}90 \text { male } C D-1 \\
\text { strain of mice }\end{array}$ & $\begin{array}{l}\text { Root bark extract from Rauwolfia vomitoria produced better behavioural effects with less distortion in motor coordination } \\
\text { when compared to chlorpromazine and so has a great potential as an alternative antipsychotic agent compared to } \\
\text { chlorpromazine. }\end{array}$ \\
\hline $\begin{array}{l}\text { Kasper } \\
\text { et al }[23] \\
(2010)\end{array}$ & $\begin{array}{l}\text { International Clinical } \\
\text { Psychopharmacology }\end{array}$ & $\begin{array}{l}221 \text { adults } \\
\text { suffering from } \\
\text { anxiety disorders. }\end{array}$ & $\begin{array}{l}\text { Lavandula oil preparation silexan is both efficacious and safe for the relief of anxiety disorder not otherwise specified. It } \\
\text { has a clinically meaningful anxiolytic effect and alleviates anxiety related to disturbed sleep. }\end{array}$ \\
\hline $\begin{array}{l}\text { Dai et al } \\
\text { [20] } \\
(2010)\end{array}$ & $\begin{array}{l}\text { Journal of } \\
\text { Ethnopharmacology }\end{array}$ & $\begin{array}{l}48 \text { male Sprague- } \\
\text { Dawley }\end{array}$ & $\begin{array}{l}\text { In term of anti-depression effect, high dose xiaoyaosan was the most effective and amitriptyline equaled middle dose } \\
\text { xiaoyaosan as shown by metabolomics strategy and behavior tests. }\end{array}$ \\
\hline $\begin{array}{l}\text { Zhou et al } \\
{[18](2010)}\end{array}$ & $\begin{array}{l}\text { Pharmacology, } \\
\text { biochemistry, and } \\
\text { behavior. }\end{array}$ & $\begin{array}{l}\text { Male Kunming } \\
\text { mice }\end{array}$ & $\begin{array}{l}\text { It was demonstrated that acute and sub-chronic administration of extracts of Fructus Akabiae produced antidepressant- } \\
\text { like effects. The results suggest that the extracts of Fructus Akebiae exert antidepressant activity. }\end{array}$ \\
\hline
\end{tabular}


Guilmatre Archives of General 28 candidate loci

et al [92] Psychiatry

(2009)

McKenna

et al [15]

(2011)

Teranishi

et al [44]

(2013)

Journal of Clinical

Psychopharma-

cology.
Approximately

300 Amazonian

species

90 patients with dementia

Recurrent or overlapping Copy Number Variations (CNVs) were found in cases at 39.3\% of the selected loci. The collective frequency of CNVs at these loci is significantly increased in cases with autism, in cases with schizophrenia, and in cases with mental retardation compared with controls $(P<.001, P=.01$, and $P=.001$, respectively, Fisher exact test). Individual significance ( $P=.02$ without correction for multiple testing) was reached for the association between autism and a 350-kilobase deletion located at 22q11 and spanning the PRODH and DGCR6 genes.

Ninety-one samples displayed $\geq 60 \%$ inhibition of radioligand binding activity in receptor assays; 135 samples displayed agonist or antagonist activity (or both) in functional assays

\begin{tabular}{|c|c|c|}
\hline $\begin{array}{c}\text { Knorle R } \\
\text { [59] (2012) }\end{array}$ & $\begin{array}{l}\text { Journal of Neural } \\
\text { Transmission }\end{array}$ & S.scardica extracts \\
\hline $\begin{array}{l}\text { Umezu T } \\
\text { [11] (2012) }\end{array}$ & $\begin{array}{l}\text { Phytotherapy } \\
\text { research: PTR }\end{array}$ & $\begin{array}{l}20 \text { plant-derived } \\
\text { essential oils (EOs) }\end{array}$ \\
\hline $\begin{array}{l}\text { Hope et al } \\
\text { [93] (2013) }\end{array}$ & $\begin{array}{l}\text { Schizophrenia } \\
\text { Research }\end{array}$ & $\begin{array}{l}322 \text { patients with } \\
\text { schizophrenia } \\
\text { spectrum and } \\
\text { bipolar disorder }\end{array}$ \\
\hline
\end{tabular}

Mean Neuropsychiatric Inventory in Nursing Home Version total score decreased in all 3 drug groups, with no significant between-group differences. Mini-Mental State Examination and Functional Independence Measure scores did not change significantly. Drug-Induced Extra-Pyramidal Symptoms Scale scores did not change in the yokukansan and fluvoxamine groups, but increased significantly in the risperidone group. Risperidone, yokukansan, and fluvoxamine were equally effective in the treatment of BPSD in elderly patients. However, yokukansan or fluvoxamine for BPSD showed a more favorable profile in tolerability compared with risperidone.

EC50 values were in the range of 30-40 $\mathrm{g} / \mathrm{ml}$. Inhibition of the human serotonin transporter by the methanol extract was even more effective (EC50 $1.4 \mathrm{lg} / \mathrm{ml})$. Combining Sideritis ethanol extract and fluvoxamine resulted in a leftward shift of the fluvoxamine concentration-response curve.

Essential oils of peppermint and chamomile exhibited CNS stimulant-like effects; that is, they increased the response rate (number of shuttlings/min) of the avoidance response. Linden also increased the response rate, however, the effect was not dose-dependent. In contrast, EOs of orange, grapefruit, and cypress exhibited CNS depressant-like effects; that is, they decreased the response rate of the avoidance response. Essential oils of eucalyptus and rose decreased the avoidance rate (number of avoidance responses/number of avoidance trials) without affecting the response rate, indicating that they may exhibit some CNS acting effects. Essential oils of 12 other plants, including juniper, patchouli, geranium, jasmine, clary sage, neroli, lavender, lemon, ylang-ylang, niaouli, vetivert and frankincense had no effect on the avoidance response in mice.

After controlling for confounders, IL-1Ra and TNF-R1 were independently associated with Global Assessment of Functioning (GAF), and significantly correlated with Positive and Negative Syndrome Scale (PANSS) negative and positive, respectively. In addition, II-1Ra was associated with premorbid adjustment scale (PAS), and sTNF-R1 with number of hospitalizations and psychotic episodes. Von Willebrand factor (VWf) was significantly corre lated with psychotic episodes, osteoprotegerin (OPG) with hospitalizations and IL-6 with history of psychosis. Linear regression analysis showed that GAF remained associated with sTNF-R1 and IL-1Ra with PANSS, after controlling for the other clinical measures. 
Tost et al Neuropsychophar- 85 healthy

[96] (2013) macology Caucasian adults

Wang et al Molecular brain ACC neurons

[28] (2012) of adult mice

overexpressing

dominant active

CREB mutant.

\begin{tabular}{c|l|l|}
$\begin{array}{c}\text { Unternaehrer } \\
\text { et al [100] }\end{array}$ & $\begin{array}{l}\text { Nature Transl } \\
\text { Psychiatry }\end{array}$ & $\begin{array}{l}76 \text { adults-43 } \\
\text { women and } \\
33 \text { men-aged } \\
\text { between } 61 \text { and } \\
67 \text { years }\end{array}$ \\
\hline
\end{tabular}

Corvin AP Cell adhesion \& 28 CAM genes

9] (2010) Migration

(9)

\begin{tabular}{c|l|l|}
$\begin{array}{c}\text { Sharkar } \\
\text { et al [1] }\end{array}$ & Journal of Herbs & 111 medicinal \\
(2013) & plants belonging \\
to 62 families
\end{tabular}

Camacho- Neurobiology of

Garcia et Diseasea

al [134]

(2012)

Sarris et al

[58] (2013)
86 cases with autism and menta retardation and 200 controls

75 participants Journal of Clinical Psychopharmacology.
Prior imaging genetics work, are consistent with complex effects of the BDNF Val66Met polymorphism on human brain structure, and may serve to generate hypotheses about variation in white matter microstructure in mental disorders associated with this variant.

CREB contributes to the regulation of fragile $X$ mental retardation protein.

They found different DNA methylation states in the OXTR when comparing pre-stress, post-stress and 90-min follow-up stress measurement.

ASDs and psychotic disorders may involve overlapping molecular aetiology where an accumulation of small effects from many common genetic risk variants or more highly penetrant mutations induce neuronal dysconnectivity by disrupting CAM function.

Assessments of reported ethnomedicinal activity indicated that these plant species can potentially lead to the discovery of novel compounds of pharmacological interest.

They Reported the identification of four novel independent mutations that affect nearby positions in two regions of the

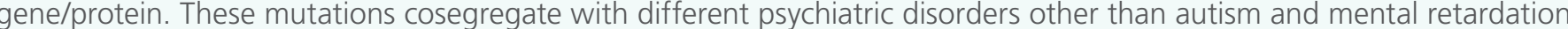
such as psychosis and attention-deficit/hyperactivity disorder.

comorbid mood

disorder
Standardized kava may be a moderately effective short-term option for the treatment of generalized anxiety disorder (GAD). Furthermore, specific GABA transporter polymorphisms appear to potentially modify anxiolytic response to kava. 
Yokukansan was developed in 1555 by Xue Kai and is one of the traditional Japanese medicines called kampo medicines in Japan $[44,45]$. In the traditional use of yokukansan, it is useful for curing screaming attacks, sleep terrors and hypnicmyoclonia, especially in children [46] .It has been approved by the Ministry of Health, Labour and Welfare of Japan as a remedy for neurosis, insomnia, and irritability in children [44, 45]. In addition, yokukansan could be useful as one of the therapeutic drugs for the treatment of anxiety disorders and various mental disorders that have comorbid anxiety [46].

Xiaoyaosan (XYS), a well-known formula for relieving depression, was originated from the book of "Taiping HuiminHejiJufang" in Song Dynasty (960-1279 AD), consisting of Radix Bupleuri, Radix Angelicae Sinensis, Radix Paeoniae Alba, Rhizoma Atractylodis Macrocephalae, Poria, Radix Glycyrrhizae, HerbaMenthae, and Rhizoma Zingiberis Recens with dose proportion of $6: 6: 6: 6: 6: 3: 2: 2$. In traditional Chinese medicine (TCM), the XYS decoction exerts various actions, including smoothing the liver, improving the circulation of Qi to relieve depression, strengthening the spleen, and nourishing blood [16].

The German Commission E, an independent body appointed by the German Federal Health Agency in 1978 to analyze and assess the information regarding herbal medicines compiled from evidence based as well as from traditional sources, has approved lavender flowers (Lavandulaeflos) for the treatment of restlessness, insomnia, and nervous disorders of the intestines [23, 47]. Psychological and psychiatric research involving lavender preparations has been focused on the drugs' relaxing, anxiolytic and mood alleviating [23, 48-56].

Fructus Akebiae is the dry fruit of Akebiaequinata (THUNB.) DECNE., a well-known medicinal plant widely distributed in China. It is recorded in the Compendium of Materia Medica that Fructus Akebiae is the major ingredient in some complex pres- criptions for treating mental disorders and cognitive and behavioral deficits, including insomnia and dreaminess, loss of memory, paraphasia, phobia, and depressive disorder etc. Previous studies reveal that the genus Akebiae contains more than thirty types of triterpenoid saponins, and most of these triterpenoid saponins comprise hederagenin $[18,57]$.

Kava is a South Pacific plant medicine with traditional cultural use as an inebriant and modern clinical use as an anxiolytic. Kava extracts are, however, still currently available in the United States, Australia, and the South Pacific Islands. In response to safety concerns, the World Health Organization commissioned a report assessing the risk of kava products. Recommendations from this report suggest that products from water-based suspensions should be developed and tested in clinical studies and that these formulations should preferentially be used over acetonic and ethanolic extracts [58].

Within the Mediterranean area the pharmacological profile of Sideritis scardica extracts as triple monoamine reuptake inhibitors suggests their use in the phytochemical therapy of mental disorders associated with a malfunctioning monoaminergic neurotransmission, such as anxiety disorders, major depression, attention-deficit hyperactivity disorder, mental impairment or neurodegenerative diseases. The genus Sideritis (Lamiaceae) comprises about 150 species distributed mainly in the Mediterranean area and in the moderate zones of Asia [59].

One of the herbs used for the treatment of psychiatric disorders in Nigeria is Rauwolfia vomitoria Afzelius which belongs to the family Apocynaceae $[60,61]$. Herbal preparations of Rauwolfia vomitoria are used by traditional medicine practitioners in the treatment of mental disorder, as demonstrated by decreased anxiety related behaviour in the mice [60]. 


\section{Relationship of mechanisms of action of potential biopharmaceuticals and their correlated diseases}

It has been reported that EOs of lavender [11, 62, 63], roman chamomile [11, 64], neroli $[11,63,65]$ and sandalwood $[11,63]$ might exhibit CNS depressant-like effects, whereas EOs of lemon $[11,66]$, jasmine $[11,67]$, rosemary $[11,68]$ and sage $[11,69]$ might exhibit CNS stimulant-like effects [11].

The serotonin system mediates a wide variety of functions including perception, emotion, attention, and cognition $[15,70]$. Serotonin receptors putatively involved in the mediation of cognitive functions include $5 \mathrm{HT}_{1 \mathrm{~A}}, 5 \mathrm{HT}_{2 \mathrm{~A}}, 5 \mathrm{HT}_{4}$, and $5 \mathrm{HT}_{6}$; not surprisingly these are promising targets for development of cognition-enhancing medications $[15,71,72]$.

A disturbance in the glutamatergic system may be associated with Behavioral and Psychological Symptoms of Dementia (BPSD). Yokukansan improved glutamate uptake and inhibited glutamate-induced neuronal death in a dose-dependent manner, thereby exerting a neuroprotective effect by improvement of the dysfunction of astrocytes. It seems that protection of the neuronal cells by glutamate uptake may be involved in the mechanisms of yokukansan [44]. However, yokukansan produced anxiolytic effects mediated through $5-\mathrm{HT}_{1 \mathrm{~A}}$ receptors on the learned fear [46].

The extracts of different parts of Stachystibetica had different anxiolytic effects, and the effects may be due to the presence of different classes of chemical constituents and variation in their concentration. The other reason for the effects may be due to the synergism and antagonism actions and competence towards the receptors like benzodiazepines, serotonins, GABA, dopamines, adrenergic, cholinergic, histamines, etc [10].

Lavender oil potentiated the binding of GABA on GABAA receptors in Xenopus oocytes $[23,73]$ and showed spasmolytic activity in a guinea-pig ileum smooth muscle preparation [20,74].
Numerous in vivo and in vitro models suggest several mechanisms by which kava may mediate a broad spectrum of psychopharmacologic actions from its psychoactive constituents, known as kavalactones. These actions include blockade of voltage-gated sodium ion channels, reduced excitatory neurotransmitter release from blockade of calcium ion channels, enhanced ligand binding to F-aminobutyric acid (GABA) type $A$ receptors, reversible inhibition of monoamine oxidase $B$, inhibition of cyclooxygenase, and reduced neuronal reuptake of dopamine and noradrenaline $[58,75-$ 84].

Recently, the effects of Sideritis preparations on the central nervous system have come into the focus of research. Aqueous and alcoholic extracts of $S$. scardica have turned out to act as triple monoamine reuptake inhibitors in vitro, inhibiting the uptake of serotonin, noradrenaline and dopamine by their respective transporters. These findings allow new perspectives on the potential use of S. scardica extracts, as he pharmaceutical industry has made considerable efforts to develop chemically defined triple monoamine reuptake inhibitors [59].

\section{Comparison among biopharmaceuticals and other drugs well established on the market}

According to Teranishiet al [44], severe adverse events were experienced by 11 patients: 5 in the risperidone group, 3 in the yokukansan group, and 3 in the fluvoxamine group. Improvements in Neuropsychiatric Inventory in Nursing Home Version (NPI-NH) score suggested that risperidone, yokukansan, and fluvoxamine were equally efficacious in treating BPSD in this elderly population. Yokukansan also reduced the NPI-NH scores. None of risperidone, yokukansan, or fluvoxamine impaired cognitive function measured by Mini-Mental State Examination (MMSE) and daily life function measured by Functional Independence Measure 
(FIM) throughout the 8-week period. Yokukansan and fluvoxamine would be generally better tolerated compared with antipsychotic drugs, such as risperidone [44].

Peppermint (MINT) and Chamomile (CHA) exhibited CNS stimulant-like effects; that is, they increased the response rate. Linden also increased the response rate. Orange (ORA), grapefruit (GRAP) and cypress (CYP) exhibited CNS depressant-like effects; that is, they decreased the response rate. The eucalyptus (EUC) and rose (ROS) oils might also act as CNS depressants because they decreased the avoidance rate. However, these two EOs are distinguishable from typical CNS depressants examined in the present study, including chlorpromazine (CPZ), haloperidol (HAL), diazepam (DZ) and physostigmine (PHYS), as EUC and ROS did not produce any effects on the response rate [11].

Kumar et al [10] have reported that All of the extracts of Stachystibetica at a dose of 200 and $400 \mathrm{mg} \cdot \mathrm{kg}^{-1}$ significantly increased the percentage of time spent and the arm entries in the open arms, and decreased the number of entries and duration of time spent in the closed arms. In a similar fashion, the standard drug, diazepam, increased the percentage of time spent and the percentage of arm entries in the open arms. Additionally, all of the extracts and DZ decreased the time spent at the center of the maze or the latency along with closed arm returns and the DZ and methanol extract of the whole plant of Stachystibetica (SMW) did not show the fecal bolus while other groups had reduced fecal bolus (**P $<0.01$ ), as compared to control, showing that the behavioral alterations induced by the extracts in the Elevated Plus Maze (EPM) are consistent with an anxiolytic effect, similar to that of diazepam [10].

The anxiolytic action of lavender is supported by several small or medium-sized clinical trials [23, 45-52]. Furthermore, were demonstrated that well-defined preparation from Lavandula angustifolia in an immediate release capsule, silexan, administered orally at a dose of $80 \mathrm{mg} /$ day is both efficacious and safe for relief of anxiety disorder not otherwise specified (NOS). The drug was determined to have a meaningful anxiolytic effect and to alleviate anxiety related disturbances of sleep while improving the physical and mental well-being. Taking into account that the tolerability of the herbal extract was on one level with placebo, the absence of unwanted sedative effects and the convenient once daily administration of silexan may emerge as a gentle therapeutic alternative in the treatment of anxiety [23].

\section{Genetic variations and gene therapy perspectives related to mental disorders}

Recently, Guilmatre et al [92] collected information in different sources about candidates for a possible gene therapy and their pathways, elucidating which location of a gene can be responsible for each related mental disorder [92].

The underlying pathological mechanisms of severe mental disorders are still largely unknown. The disorders are highly heritable $[93,94]$ with complex genetic and environmental interactions involved [93, 95]. However, the specific mechanisms involved remain elusive [93].

In recent years, imaging genetics has emerged as a popular approach with which to explore the effects of genetic variation on measures of brain structure and function, but initial studies are often followed by inconsistent results. Among others, BDNF Val66Met has previously been implicated as genetic risk factor for bipolar disorder, schizophreniadepression [96, 97-99]. Additionally, Tost et al [96] have found evidence of BDNF Val66Met genotype effects on white matter microstructure in healthy young Caucasian adults manifesting as reductions in measures of coherent spatial orientation of white matter in Val/Val homozygotes, which may serve to generate hypotheses about the changes in white matter structure in disorders that have 
been associated with the Val allele, even though between-study differences in methods may contribute to the observed heterogeneity in genetic association findings [96].

Disruption of a number of these genes (including NRXN1, CNTNAP2 and (ASK) are known to cause diverse neurodevelopmental brain disorder phenotypes including schizophrenia, autism, learning disability and specific language disorder. Taken together these studies bring the cell adhesion molecule (CAM) pathway sharply into focus for more comprehensive DNA sequencing to identify the critical genes, and investigate their relationships and interaction with environmental risk factors in the expression of many seemingly different neurodevelopmental disorders [9].

DNA methylation is an epigenetic mechanism related to mental and physical health and disease. Aberrant DNA methylation has been implicated in the etiology of various mental disorders including, depression, psychotic disorders, post-traumatic stress disorder, autism, eating disorders, and substance dependence but also has an important role in the pathology of physical illnesses, such as cancer. Thereby DNA methylation provides a biological basis for gene-environment interactions relevant to mental health, animal and human studies have found that early life experiences can alter DNA methylation and affect gene expression and behavior [100, 101-131].

It was found methylation stress-associated DNA changes in one of two OXTR target sequences but not in the assessed target sequence of BDNF, suggesting a considerable variation in the sensitivity of short-term DNA methylation responses among different stress-related genes. For OXTR1, we found an increase in DNA methylation from pre-stress to post-stress and a decrease from poststress to follow-up. In OXTR2, methylation decreased from post-stress to follow-up only. Notably, in OXTR1 the time-associated changes, as well as the difference from post-stress to follow up, re- mained significant even after controlling for blood cell count [100].

Regarding BDNF, our results suggest that in the periphery, DNA methylation in BDNF remains stable after a short and non-recurring psychosocial stressor. Previous studies found lifelong and transgenerational perpetuation of changes in BDNF methylation after early-life adversity [100, 131]. Fuchikami et al [132] recently suggested DNA methylation of BDNF in peripheral blood as a diagnostic biomarker of major depression [100, 132]. These results and our finding implicate that BDNF methylation has a long-term, rather than a short-term, role in stress adaptation [100].

The added novel finding of the study, concerning a possible association of specific genetic variants within the SLC6A1 locus encoding GABA transporter modify response, is intriguing; kava is known to affect anxiolytic activity from the kavalactone constituents effects on GABA pathways. Although not directly related to pharmacodynamics drug response, a study by Thoeringer et al [133] found that the frequency of the GABA transporter rs2697153 G-allele is significantly more prevalent in people with anxiety disorders, with the protective effect of those with A-alleles having an odds ratio of 2.17 (95\% confidence interval, 1.46Y3.24) [58, 133]. Interestingly, our findings suggest that the number of A-alleles corresponds with the likelihood of a favorable response to kava [58].

In the last years, mutations in neurexin and neuroligin genes have been associated with Autism Spectrum Disorders (ASD), such as the identification of four novel mutations of $N R X N 1 \beta$ in a sample of 86 patients with autism and Mental Retardation that in larger populations combined with functional analysis of ASD-associated mutations will help clarify the disease mechanisms [134].

Fragile $X$ syndrome is caused by lack of fragile $X$ mental retardation protein (FMRP) due to silencing of the FMR1 gene. The metabotropic glutamate 
receptors (mGluRs) in the central nervous system contribute to higher brain functions including learning/memory, mental disorders and persistent pain. The transcription factor cyclic AMP-responsive element binding protein (CREB) is involved in important neuronal functions, such as synaptic plasticity and neuronal survival. It was shown in previous studies that stimulation of Group I mGluRsupregulated FMRP and activated CREB in anterior cingulate cortex (ACC), a key region for brain cognitive and executive functions, suggesting that activation of Group I mGluRs may upregulate FMRP through CREB signaling pathway. Therefore, was proposed that CREB is the key transcription factor in regulation of FMRP by Group I mGluRs in ACC neurons, and may help to further elucidate the molecular and cellular mechanisms underlying fragile $X$ syndrome [28].

\section{Conclusion}

Many plants and natural entities have been used as sources of biomolecules that may be used as biopharmaceuticals to treat, cure or mitigate mental disorders. In this review, no approved biopharmaceutical was found within the last 5 years to treat mental disorders, which highlights the need of investing in this area, supported by the fact that there is a potential field where biomolecules may serve as new drugs to treat those disorders.

Several biomarkers have been related to mental disorders with regards to their level and the severity of disease, such as sTNF-R1 and IL-1Ra17. Those markers may be targets of biologics that would help to keep the level of those molecules normal. Additionally, many genes have been suggested as signatures of mental disorders, potentially opening avenues for gene therapy or therapies based on maintaining normal epigenetic profile in humans.

The popular medicine has an important role in providing natural sources that have been known as active compounds used to treat mental disorders. However, those substances have not been largely characterized and studied at a clinical level, demonstrating the field of biopharmaceuticals provides an unexplored area to be developed. Therefore, this field is significant and can revolute the future of current medicines used to treat mental disorders.

\section{Acknowledgments}

We are grateful to the Suicidology Research group - Federal University of Ceará (UFC) / National Council for Scientific and Technological Development (CNPq). We would also like to thank the Scientific Writing Lab (LABESCI) - Faculty of Medicine, Federal University of Cariri (UFCA), to the LABESCI - Biotechnology, UFC.

\section{Conflict of interest}

The authors have no conflicts of interest or financial ties to report.

\section{References}

1. PriyankaSharkar, M. MizanurRahman, GaziZiaul et al. "Ethnomedicinal importance of the plants in villages in Kushtiasador and Mirpurupozila, Bangladesh". Journal of Herbs, Spices \& Medicinal Plants (2013) 19, 401-417.

2. Farnsworth, N. R., and D. D. Soejarto. 1991. Global importance of medicinal plants. In O. Akerele, V. Heywood, and H. Synge, eds., The Conservation of Medicinal Plants. Cambridge University Press, Cambridge, UK.pp. 25-51.

3. Pei, S. 2001. Ethnobotanical approaches of traditional medicine studies: Some experiences from Asia. Pharma. Bot. 39: 74-79.

4. Balick, J. M., and P. A. Cox. 1996. Plants, People and Culture: The Science of Ethnobotany. Scientific American Library, New York. 228 pp.

5. Gilani, A. H., and A. U. Rahman. 2005. Trends in ethnopharmacology. J. Ethnopharmacol. 100: 43-49.

6. Masum, G., Z. H, P. Sharkar, M. A. Nayeem, M. Rahman, and M. M. Rahman. 2013. Medicinal plants used by Kabiraj of fourteen villages in Jhenaidah district, Bangladesh. Global J. Res. Med. Plants Indigen. Med. 2(1): 10-22. 
7. Rahmatullah, M, D. Ferdausi, M. A. H. Mollik, R. Jahan, M. H. Chowdhur, and W. M. Haque. 2010. A survey of medicinal plants used by Kavirajasof Chalna area, Khulna District, Bangladesh. Afr. J. Trade. Com. Alter. Med. 7: 91-97.

8. Comer, M., and E. Debus. 1996. A partnership: Biotechnology, biopharmaceuticals and biodiversity. In F. Di Castri and T. Younnes, eds., Biodiversity. Scienceand Development. CAB International, Oxford. pp. 488-499.

9. Aiden P. Corvin. "Neuronal cell adhesion genes". Cell Adhesion \& Migration (2010) 4: 4, 511-514

10. Dinesh Kumar, Zulfiqar Ali Bhat, Vijender Kumar et al. "Antianxiety activity of StachystibeticaVatke". Chinese Journal of Natural Medicines 2013, 11(3): 0240-0244.

11. ToyoshiUmezu. "Evaluation of the Effects of Plant-derived Essential Oils on Central Nervous System Function Using Discrete Shuttle-type Conditioned Avoidance Response in Mice".Phytother. Res. 2012. 26: 884-891.

12. Balchin ML. 1997. Essential oils and 'aromatherapy': their modern role in healing. J R Soc Health 117: 324-329.

13. Buckle J. 1999. Use of aromatherapy as a complementary treatment of chronic pain. AlternTher 5: 42-51.

14. Perry N, Perry E. 2006. Aromatherapy in the management of psychiatric disorders-Clinical and neuropharmacological perspectives.CNS Drugs 20: 257-280.

15. Dennis J. McKenna, Juan M. Ruiz, Thomas R. Hoy et al. "Receptor screening technologies in the evaluation of Amazonian ethnomedicines with potential applications to cognitive deficits". Journal of Ethnopharmacology 134 (2011) 475-492.

16. XiaoxiaGaoa, XingyuZhenga, Zhenyu Li et al. "Metabonomic study on chronic unpredictable mild stress and intervention effects of Xiaoyaosan in rats using gas chromatography coupled with mass spectrometry". Journal of Ethnopharmacology 137 (2011) 690-699.

17. Peet M, Murphy B, Shay J, Horrobin D. "Depletion of omega-3 fatty acid levels in red blood cell membranes of depressive patients". Biological Psychiatry 43 (2003), 315-319.

18. Dan Zhou, Hong Jin, Huan-Bing Lin et al. "Antidepressant effect of the extracts from FructusAkebiae". Pharmacology, Biochemistry and Behavior 94 (2010) 488-495.

19. Schechter LE, Ring RH, Beyer CE, Hughes ZA, Khawaja $X$, Malberg JE, et al. Innovative approaches for the development of antidepressant drugs: current and future strategies. NeuroRx 2005;2: 590-611.

20. Yuntao Dai, Zhenyu Li, Liming Xue et al. "Metabolomics study on the anti-depression effect of xiaoyaosan on rat model of chronic unpredictable mild stress". Journal of Ethnopharmacology 128 (2010) 482-489.
21. $\mathrm{Xu}, \mathrm{Z} . W ., \mathrm{Wu}$, L.L., Ya, V.C., 2003. The experimental research on anti-depression effects of xiaoyaosan decoction and danzhixiaoyaosan decoction.Acta Chinese Medicine and Pharmacology 31, 61.

22. Zhao, X.J., Zhang, Y., Meng, X.L., Yin, P.Y., Deng, C., Chen, J., Wang, Z., Xu, G.W., 2008a. Effect of a traditional Chinese medicine preparation Xindi soft capsule on rat model of acute blood stasis: a urinary metabonomics study based on liquid chromatography-mass spectrometry. Journal of Chromatography B 873, 151-158.

23. Siegfried Kasper, Markus Gastpar, Walter E. Muller et al. "Silexan, an orally administered Lavandula oil preparation, is effective in the treatment of 'subsyndromal' anxiety disorder: a randomized, double-blind, placebo controlled trial". International Clinical Psychopharmacology 2010, 25: 277-287.

24. Hidalgo RB, Davidson JR (2001). Generalized anxiety disorder. An important clinical concern. Med Clin North Am 85: 691-710.

25. Kessler RC, McGonagle KA, Zhao S, Nelson CB, Hughes M, Eshleman S, et al. (1994). Lifetime and 12-month prevalence of DSM-III-R psychiatric disorders in the United States. Results from the National Comorbidity Survey. Arch Gen Psychiatry 51: 8-19.

26. Andrews G, Carter GL (2001).What people say about their general practitioners' treatment of anxiety and depression. Med J Aust 175 (Suppl): S48-S51.

27. Bandelow B, Zohar J, Hollander E, Kasper S, Moller HJ, Zohar J, et al. (2008). World Federation of Societies of Biological Psychiatry (WFSBP) guidelines for the pharmacological treatment of anxiety, obsessive-compulsive and posttraumatic stress disorders-first revision.World J Biol Psychiatry 9: 248-312.

28. Hansen Wang, Yoshikazu Morishita, Daiki Miura et al. "Roles of CREB in the regulation of FMRP by group I metabotropic glutamate receptors in cingulate cortex". Molecular Brain 2012, 5: 27.

29. Belmonte MK, Bourgeron T: Fragile $X$ syndrome and autism at the intersection of genetic and neural networks. Nat Neurosci 2006, 9(10): 1221-1225.

30. Bhakar AL, Dolen G, Bear MF: The Pathophysiology of Fragile $X$ (and What It Teaches Us about Synapses). Annu Rev Neurosci 2012, 2012: 2012

31. Feng $Y$, Zhang F, Lokey LK, Chastain JL, Lakkis L, Eberhart D, Warren ST: Translational suppression by trinucleotide repeat expansion at FMR1. Science 1995, 268(5211): 731-734.

32. Garber KB, Visootsak J, Warren ST: Fragile X syndrome. Eur J Hum Genet 2008, 16(6): 666-672.

33. Huber K: Fragile X syndrome: molecular mechanisms of cognitive dysfunction. Am J Psychiatry 2007, 164(4): 556.

34. Jin $P$, Warren ST: New insights into fragile $X$ syndrome: from molecules to neurobehaviors. Trends BiochemSci 2003, 28(3): 152-158. 
35. Santoro MR, Bray SM, Warren ST: Molecular mechanisms of fragile X syndrome: a twenty-year perspective. Annu Rev Pathol 2011, 7: 219-245

36. Krueger DD, Bear MF: Toward fulfilling the promise of molecular medicine in fragile X syndrome. Annu Rev Med 2011, 62: 411429

37. Wang T, Bray SM, Warren ST: New perspectives on the biology of fragile X syndrome. CurrOpin Genet Dev 2012, 22(3): 256 263.

38. Fava M. Diagnosis and definition of treatment-resistant depression. Biol Psychiatry 2003;53: 649-59.

39. Antai-Otong D. Antidepressant-induced insomnia: treatment options. PerspectPsychiatr Care 2004;40: 29-33.

40. Baldwin D, Bridgman $K$, Buis $C$. Resolution of sexual dysfunction during double-blind treatment of major depression with reboxetine or paroxetine. J Psychopharmacol 2006;20: 91-6.

41. Khurana RN, Baudendistel TE. Hypertensive crisis associated with venlafaxine. Am J Med 2003;115: 676-7.

42. Park IY, Kim EJ, Park H, Fields K, Dunker AK, Kang C. Interaction between cardiac calsequestrin and drugs with known cardiotoxicity. MolPharmacol 2005;67: 97-104.

43. D. Kumar et al. Effects of Stachystibetica essential oil in anxiety (2012). European Journal of Integrative Medicine 4(2) e169-e176

44. Mika Teranishi, Masatake Kurita, Satoshi Nishino et al. "Efficacy and Tolerability of Risperidone, Yokukansan, and Fluvoxamine for the Treatment of Behavioral and Psychological Symptoms of Dementia: A Blinded, Randomized Trial". J ClinPsychopharmacol 2013;33: 600 - 607

45. Iwasaki K, Satoh-Nakagawa T, Maruyama M, et al. A randomized, observer-blind, controlled trial of the traditional Chinese medicine yi-gan san for improvement of behavioral and psychological symptoms and activities of daily living in dementia patients. J Clin Psychiatry. 2005;66(2): 248Y252.

46. Taku Yamaguchi, Aki Tsujimatsu, Haruko Kumamoto et al. "Anxiolytic effects of yokukansan, a traditional Japanese medicine, via serotonin 5-HT1A receptors on anxiety-related behaviors in rats experienced aversive stress". Journal of Ethnopharmacology 143 (2012) 533-539.

47. Bundesgesundheitsamt (1984). Monographie-Lavandulaeflos (Lavendelblu" ten).Bundesanzeiger 228 (December 5, 1984).

48. Louis M, Kowalski SD (2002). Use of aromatherapy with hospice patients to decrease pain, anxiety, and depression and to promote an increased sense of well-being. Am J HospPalliat Care 19: 381-386.

49. Motomura N, Sakurai A, Yotsuya Y (2001). Reduction of mental stress with lavender odorant.Percept Mot Skills 93: 713-718.

50. Morris N (2002). The effects of lavender (Lavendulaangustifolium) baths on psychological well-being: two exploratory randomised control trials. Complement Ther Med 10: 223-228.
51. Akhondzadeh S, Kashani L, Fotouhi A, Jarvandi S, Mobaseri M, Moin M, et al. (2003). Comparison of Lavandulaangustifolia Mill tincture and imipramine in the treatment of mild to moderate depression: a double-blind, randomized trial. ProgNeuropsychopharmacolBiol Psychiatry 27: 123-127.

52. Field T, Diego M, Hernandez-Reif M, Cisneros W, Feijo L, Vera $Y$, et al. (2005). Lavender fragrance cleansing gel effects on relaxation. Int J Neurosci 115: 207-222.

53. Lehrner J, Marwinski G, Lehr S, Johren P, Deecke L (2005). Ambient odors of orange and lavender reduce anxiety and improve mood in a dental office. PhysiolBehav 86: 92-95.

54. Lin PW, Chan WC, Ng BF, Lam LC (2007). Efficacy of aromatherapy (Lavandulaangustifolia) as an intervention for agitated behaviours in Chinese older persons with dementia: a cross-over randomized trial. Int J Geriatr Psychiatry 22: 405410.

55. Bradley BF, Brown SL, Chu S, Lea RW (2009). Effects of orally administered lavender essential oil on responses to anxietyprovoking film clips. Hum Psychopharmacol 24: 319-330.

56. McCaffrey R, Thomas DJ, Kinzelman AO (2009). The effects of lavender and rosemary essential oils on test-taking anxiety among graduate nursing students. Holist NursPract 23: 88-93.

57. Jiang D, Gao QP, Shi SP, Tu PF. Triterpenoidsaponins from the fruits of Akebiaequinata. Chem Pharm Bull (Tokyo) 2006;54: 595-7.

58. Jerome Sarris, Con Stough, , Chad A. Bousman et al. "Kava in the Treatment of Generalized Anxiety Disorder A Double-Blind, Randomized, Placebo-Controlled Study" Journal of Clinical Psychopharmacology (2013) 33, 643-64.

59. Rainer Knorle. "Extracts of Sideritisscardica as triple monoamine reuptake inhibitors".J Neural Transm (2012) 119: 1477-1482.

60. Sunday AgbaBisong, Richard Brown, EmeEffiomOsim. "Comparative effects of Rauwolfiavomitoria and chlorpromazine on locomotorbehaviour and anxiety in mice". Journal of Ethnopharmacology 132 (2010) 334-339.

61. Akpanabiatu, M.I., Umoh, I.B., Eyong, E.U., 2006. Influence of Rauwolfiavomitoria root bark on cardiac enzymes o normal Wistar albino rats. Recent Progress in Medicinal Plants 14, 273278

62. Buchbauer G, Jirovetz L, Jäger W. 1991. Aromatherapy: evidence for sedative effects of the essential oil of lavender after inhalation. Z Naturforsch 46c: 1967-1972.

63. Buchbauer G, Jirovetz L, Jäger W, Plank C, Dietrich H. 1993. Fragrance compounds and essential oils with sedative effects upon inhalation. J Pharm Sci 82: 660-664.

64. Rossi T, Melegari M, Bianchi A, Albasini A, Vampa G, 1988. Sedative, anti-inflammatory and anti-diuretic effects induced in rats by essential oils of varieties of Anthemisnobilis: a comparative study. Pharmacol Res Commun 20(Suppl 5): 7174. 
65. Carvalho-Freitas MI, Costa M. 2002. Anxiolitic and sedative effects of extracts and essential oil of Cirusarutanium L. Biol Pharm Bull 25: 1629 - 1633

66. Komori T, Fujiwara R, Tanida M, Nomura J. 1995. Potential antidepressant effects of lemon odor in rats.Eur $J$ Neuropsychopharmacol 5: 477 - 480

67. Tsuchiya T, Tanida M, Uenoyama S, Nakayama Y. 1992. Effects of olfactory stimulation with jasmine and its component chemicals on the duration of pentobarbital-induced sleep in mice.Life Sci 50: 1097-1102.

68. Kovar KA, Gropper B, Friess D, Ammon HP. 1987. Blood levels of 1,8-cineol and locomotor activity of mice after inhalation and oral administration of rosemary oil.Planta Med 53: 315318.

69. Wake G, Court J, Pickering A, Lewis, R, Wilkins R, Perry E. 2000. CNS acetylcholine receptor activity in European medicinal plants traditionally used to improve failing memory. J Ethnopharmacol 69: 105-114.

70. Berger, M., Gray, J.A., Roth, B.L., 2009. The expanded biology of serotonin. Annual Review of Medicine 60, 355-366.

71. Roth BL, Hanizavareh SM, Blum AE. 2004b. Serotonin receptors represent highly favorable molecular targets for cognitive enhancement in schizophrenia and other disorders. Psychopharmacology (Berlin) 174, 17 - 24

72. Gray, J.A., Roth, B.L., 2007b. Molecular targets for treating cognitive dysfunctions in schizophrenia. Schizophrenia Bulletin 33, 1100-1119.

73. Aoshima H, Hamamoto K (1999). Potentiation of GABAA receptors expressed in Xenopus oocytes by perfume and phytoncid. BiosciBiotechnolBiochem 63: 743-748.

74. Lis-Balchin M, Hart S (1999). Studies on the mode of action of the essential oil of lavender (Lavandulaangustifolia P. Miller). Phytother Res 13: 540-542.

75. 75, LaPorte E, Sarris J, Stough C, et al. Neurocognitive effects of kava (Piper methysticum): a systematic review. Hum Psychopharmacol. 2011;26(2): 102Y111.

76. Magura El, Kopanitsa MV, Gleitz J, et al. Kava extract ingredients, (+)-methysticin and (+/j)-kavain inhibit voltageoperated $\mathrm{Na}(+)$-channels in rat CA1 hippocampal neurons. Neuroscience. 1997;81(2): 345Y351.

77. Gleitz J, Beile A, Peters T. (+/-)-Kavain inhibits veratridineactivated voltage-dependent $\mathrm{Na}(+)$-channels in synaptosomes prepared from rat cerebral cortex. Neuropharmacology. 1995;34(9): 1133Y1138.

78. Martin HB, McCallum M, Stofer WD, et al. Kavain attenuates vascular contractility through inhibition of calcium channels. Planta Med. 2002;68(9): 784Y789

79. Walden J, von Wegerer J, Winter $U$, et al. Effects of kawain and dihydromethysticin on field potential changes in the hippocampus. ProgNeuropsychopharmacolBiol Psychiatry. 1997;21(4): 697Y706.
80. Jussofie A, Schmiz A, Hiemke C. Kavapyrone enriched extract from Piper methysticum as modulator of the GABA binding site in different regions of rat brain. Psychopharmacology (Berl). 1994;116(4): 469Y474.

81. Uebelhack R, Franke L, Schewe HJ. Inhibition of platelet MAO-B by kava pyrone-enriched extract from Piper methysticum Forster (kava-kava). Pharmacopsychiatry. 1998;31(5): 187Y192.

82. Wu D, Yu L, Nair M, et al. Cyclooxygenase enzyme inhibitory compounds with antioxidant activities from Piper methysticum (kava kava) roots. Phytomedicine. 2002;9: 41Y47.

83. Baum SS, Hill R, Rommelspacher H. Effect of kava extract and individual kavapyrones on neurotransmitter levels in the nucleus accumbens of rats. ProgNeuropsychopharmacolBiol Psychiatry. 1998;22(7): 1105Y1120.

84. Seitz U, Schule A, Gleitz J. [3H]-monoamine uptake inhibition properties of kava pyrones. Planta Med. 1997;63(6): 548Y549

85. Buckle J (1993). Aromatherapy. Nurs Times 89: 32-35.

86. Dunn C, Sleep J, Collett D (1995). Sensing an improvement: an experimental study to evaluate the use of aromatherapy, massage and periods of rest in an intensive care unit. J AdvNurs 21: 34-40.

87. Hardy M, Kirk-Smith MD, Stretch DD (1995). Replacement of drug treatment for insomnia by ambient odour. Lancet 346: 701.

88. Hudson R (1996). Nursing: the value of lavender for rest and activity in the elderly patient. Complement Ther Med 4: 52-57.

89. Wolfe N, Herzberg J (1996). Can aromatherapy oils promote sleep in severely demented patients? Int J Geriatr Psychiatry 11: 926-927.

90. Itai T, Amayasu H, Kuribayashi M, Kawamura N, Okada M, Momose A, et al. (2000). Psychological effects of aromatherapy on chronic hemodialysis patients.Psychiatry ClinNeurosci 54: 393-397

91. Lehrner J, Marwinski G, Lehr S, Johren P, Deecke L (2005). Ambient odors of orange and lavender reduce anxiety and improve mood in a dental office. PhysiolBehav 86: 92-95.

92. Audrey Guilmatre, ChristèleDubourg, Anne-Laure Mosca et al. "Recurrent Rearrangements in Synaptic and Neurodevelopmental Genes and Shared Biologic Pathways in Schizophrenia, Autism, and Mental Retardation". Arch Gen Psychiatry. 2009;66(9): 947-956.

93. Sigrun Hope, Thor Ueland, Nils Eiel Steen et al. "Interleukin 1 receptor antagonist and soluble tumor necrosis factor receptor 1 are associated with general severity and psychotic symptoms in schizophrenia and bipolar disorder". Schizophrenia Research 145 (2013) 36-42.

94. Harrison, P.J., Weinberger, D.R., 2005. Schizophrenia genes, gene expression, and neuropathology: on the matter of their convergence. Mol. Psychiatry 10 (1), 40-68. 
95. Burmeister, M., Mclnnis, M.G., Zollner, S., 2008. Psychiatric genetics: progress amid controversy. Nat. Rev. Genet. 9 (7)، 527-540

96. Heike Tost, TajvarAlam, Matthew Geramita et al. "Effects of the BDNF Val66Met Polymorphism on White Matter Microstructure in Healthy Adults". Neuropsychopharmacology (2013) 38, 525532

97. Sklar P et al (2002). Family-based association study of 76 candidate genes in bipolar disorder: BDNF is a potential risk locus. Brain-derived neutrophic factor. Mol Psychiatry 7: 579593.

98. Neves-Pereira M. et al (2005). BDNF gene is a risk factor for schizophrenia in a Scottish population. Mol Psychiatry 10: 208212.

99. Verhagen M. et al (2010). Meta-analysis of the BDNF Val66Met polymorphism in major depressive disorder: effects of gender and ethnicity. Mol Psychiatry 15: 260-271.

100. E Unternaehrer, P Luers, J Mill, E Dempster et al. "Dynamic changes in DNA methylation of stress-associated genes (OXTR, BDNF) after acute psychosocial stress". Translational Psychiatry (2012) 2, 1-7.

101. Docherty S, Mill J. Epigenetic mechanisms as mediators of environmental risks for psychiatric disorders. Psychiatry 2008; 7: 500-506.

102. Toyokawa S, Uddin M, Koenen KC, Galea S. How does the social environment 'get into the mind'? Epigenetics at the intersection of social and psychiatric epidemiology.SocSci Med 2012; 74: 67-74

103. National Institute of Mental Health. National Institute of Mental Health Strategic Plan, 2008.

104. Scarano MI, Strazzullo $M$, Matarazzo MR, D’Esposito $M$. DNA methylation 40 years later: Its role in human health and disease. J Cell Physiol 2005; 204: 21-35.

105. Fuchikami M, Morinobu S, Segawa M, Yamawaki S. DNA methylation profiles of the BDNF gene in patients with major depression. Int J Neuropsychopharmacol 2010; 13: 147.

106. Olsson CA, Foley DL, Parkinson-Bates M, Byrnes G, McKenzie $M$, Patton GC et al. Prospects for epigenetic research within cohort studies of psychological disorder: a pilot investigation of a peripheral cell marker of epigenetic risk for depression. BiolPsychol 2010; 83: 159-165.

107. Rotter A, Asemann R, Decker A, Kornhuber J, Biermann T. Orexin expression and promoter-methylation in peripheral blood of patients suffering from major depressive disorder. J Affect Disord 2011; 131: 186-192.

108. Uddin M, Koenen KC, Aiello AE, Wildman DE. de los Santos R, GaleaS. Epigenetic and inflammatory marker profiles associated with depression in a community-based epidemiologic sample. Psychol Med 2011; 41: 997-1007.
109. Mill J, Petronis A. Molecular studies of major depressive disorder: the epigenetic perspective. Mol Psychiatry 2007; 12: 799-814.

110. Abdolmaleky HM. Reelinhypermethylation in schizophrenia and beyond. Int J Neuropsychopharmacol 2006; 9: S37.

111. Ghadirivasfi M, Nohesara S, Ahmadkhaniha HR, Eskandari MR, Mostafavi S, Thiagalingam $S$ et al. Hypomethylation of the serotonin receptor type-2A gene (HTR2A) at T102C polymorphic site in DNA derived from the saliva of patients with schizophrenia and bipolar disorder. Am J Med Genet Part B 2011; 156B: 536-545.

112. Kuratomi G, Iwamoto K, Bundo M, Kusumi I, Kato N, Iwata $\mathrm{N}$ et al. Aberrant DNA methylation associated with bipolar disorder identified from discordant monozygotic twins. Mol Psychiatry 2008; 13: 429-441.

113. Mill J, Tang T, Kaminsky Z, Khare T, Yazdanpanah S, Bouchard $L$ et al. Epigenomic profiling reveals DNA-methylation changes associated with major psychosis. Am J Hum Genet 2008; 82: 696-711.

114. Shimabukuro M, Sasaki T, Imamura A, Tsujita T, Fuke C, Umekage $T$ et al. Global hypomethylation of peripheral leukocyte DNA in male patients with schizophrenia: a potential link between epigenetics and schizophrenia. J Psychiatr Res 2007; 41: 1042-1046.

115. Dempster EL, Pidsley R, Schalkwyk LC, Owens S, Georgiades $A$, Kane $F$ et al. Diseaseassociated epigenetic changes in monozygotic twins discordant for schizophrenia and bipolar disorder. Hum Mol Genet 2011; 20: 4786-4796.

116. Smith AK, Conneely KN, Kilaru V, Mercer KB, Weiss TE, Bradley $B$ et al. Differential immune system DNA methylation and cytokine regulation in post-traumatic stress disorder. Am J Med Genet B Neuropsychiatr Genet 2011; 156B: 700-708.

117. Uddin M, Aiello AE, Wildman DE, Koenen KC, Pawelec G, de Los Santos $R$ et al. Epigenetic and immune function profiles associated with posttraumatic stress disorder. ProcNatlAcadSci U S A 2010; 107: 9470-9475.

118. Schanen NC. Epigenetics of autism spectrum disorders. Hum Mol Genet 2006; 2: R138-R150.

119. Nguyen A, Rauch TA, Pfeifer GP, Hu VW. Global methylation profiling of lymphoblastoid cell lines reveals epigenetic contributions to autism spectrum disorders and a novel autism candidate gene, RORA, whose protein product is reduced in autistic brain. FASEB J 2010; 24: 3036-3051.

120. Frieling H, Romer KD, Scholz S, Mittelbach F, Wilhelm J, De Zwaan $\mathrm{M}$ et al. Epigenetic dysregulation of dopaminergic genes in eating disorders. Int J Eat Disord 2010; 43: 577583. 
121. Frieling $H$, Bleich $S$, Otten J, Romer KD, Kornhuber J, de Zwaan $\mathrm{M}$ et al. Epigenetic downregulation of atrial natriuretic peptide but not vasopressin mRNA expression in females with eating disorders is related to impulsivity. Neuropsychopharmacology 2008; 33: 2605-2609. 22. Wong CC, Mill J, Fernandes C. Drugs and addiction: an introduction to epigenetics. Addiction 2011; 106: 480-489.

122. Rodriguez-Paredes M, Esteller M. Cancer epigenetics reaches mainstream oncology. Nat Med 2011; 17: 330-339.

123. Meaney MJ. Epigenetics and the biological definition of gene x environment interactions.Child Dev 2010; 81: 41-79.

124. Liu D, Diorio J, Tannenbaum B, Caldji C, Francis D, Freedman A et al. Maternal care, hippocampal glucocorticoid receptors, and hypothalamic-pituitary-adrenal responses to stress. Science 1997; 277: 1659-1662.

125. McGowan PO, Sasaki A, D'Alessio AC, Dymov S, Labonte $B$, Szyf $M$ et al. Epigenetic regulation of the glucocorticoid receptor in human brain associates with childhood abuse. Nat Neurosci 2009; 12: 342-348.

126. Mueller BR, Bale TL. Sex-specific programming of offspring emotionality after stress early in pregnancy.J Neurosci 2008; 28: 9055-9065.

127. Radtke KM, Ruf M, Gunter HM, Dohrmann K, Schauer M, Meyer $A$ et al. Transgenerational impact of intimate partner violence on methylation in the promoter of the glucocorticoid receptor. Transl Psychiatry 2011; 1.

128. Weaver ICG, Cervoni N, Champagne FA, D'Alessio AC, Sharma SS Jr et al. Epigenetic programming by maternal behavior. Nat Neurosci 2004; 7: 847-854.

129. Oberlander TF, Weinberg J, Papsdorf M, Grunau R, Misri S, Devlin AM. Prenatal exposure to maternal depression, neonatal methylation of human glucocorticoid receptor gene (NR3C1) and infant cortisol stress responses. Epigenetics 2008; 3: 97106.

130.Spengler D, Murgatroyd C, Patchev AV, Wu Y, Micale V, Bockmuhl $Y$ et al. Dynamic DNA methylation programs persistent adverse effects of early-life stress. Nat Neurosci 2009; 12: 1559-U1108.
131. Roth TL, Lubin FD, Funk AJ, Sweatt JD. Lasting epigenetic influence of early-life adversity on the BDNF gene. Biol Psychiatry 2009; 65: 760-769.

132. Fuchikami M, Morinobu S, Segawa M, Okamoto Y, Yamawaki $\mathrm{S}$, Ozaki $\mathrm{N}$ et al. DNA methylation profiles of the brain-derived neurotrophic factor (BDNF) gene as a potent diagnostic biomarker in major depression. Plos One 2011; 6: 8.

133. Thoeringer CK, Ripke $S$, Unschuld PG, et al. The GABA transporter 1 (SLC6A1): a novel candidate gene for anxiety disorders. J Neural Transm. 2009;116(6): 649Y657.

134. Rafael J. Camacho-Garcia, Ma. InmaculadaPlanelles, Mar Margalef et al. "Mutations affecting synaptic levels of neurexin-1 $\beta$ in autism and mental retardation". Neurobiology of Disease 47 (2012) 135-143.

\section{Comment on this article:}

\section{$4[$ in $8+\mathbf{S} P$}

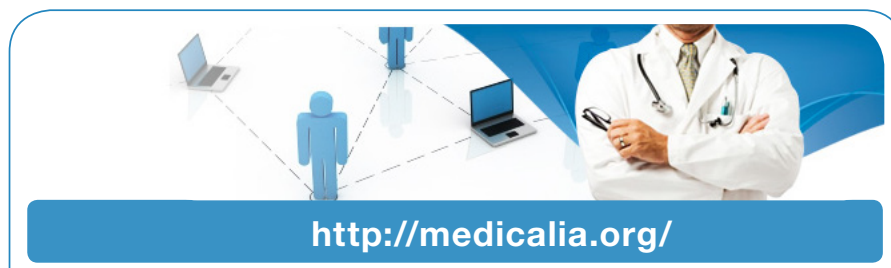

Where Doctors exchange clinical experiences, review their cases and share clinical knowledge. You can also access lots of medical publications for free. Join Now!

\section{Publish with iMedPub}

\section{http://www.imed.pub}

International Archives of Medicine is an open access journal publishing articles encompassing all aspects of medical science and clinical practice. IAM is considered a megajournal with independent sections on all areas of medicine. IAM is a really international journal with authors and board members from all around the world. The journal is widely indexed and classified Q1 in category Medicine. 